\title{
Diyabet Bakımında Ebeveyn İzleminin Adölesanlarda Tedaviye Uyum ve Metabolik Parametrelere Etkisi
}

\section{The Effect of Parental Monitoring in Diabetes Care on Compliance to Treatment and Metabolic Parameters in Adolescents}

\author{
Hakan Avan $^{1 *}$, Feride Yiğit ${ }^{2}$ \\ ${ }^{1}$ Kahramanmaraş Sütçü İmam University VSHS, Kahramanmaraş, Türkiye \\ ${ }^{2}$ İstanbul Atlas University, Faculty of Health Sciences, İstanbul, Türkiye \\ e-mail: hakanavan@gmail.com, ferideyigit@gmail.com \\ ORCID: 0000-0003-2494-3671 \\ ORCID: 0000-0001-8152-0400 \\ *Sorumlu yazar/ Corresponding Author: Hakan Avan \\ Gönderim Tarihi / Received: 10.07.2020 \\ Kabul Tarihi / Accepted: 17.11.2020 \\ DOI: $10.34087 /$ cbusbed. 765495
}

$\ddot{O} z$

Giriş ve Amaç: Çalışma, diyabet bakımında ebeveyn izlemenin ergenlerde tedaviye ve metabolik parametrelere uyum üzerindeki etkisini belirlemek amacıyla yapıldı.

Gereç ve Yöntemler: Çalışma Gaziantep Çocuk Hastanesi Endokrinoloji Polikliniğinde takip edilen 132 Tip 1 diyabetli ergenin yanı sıra ebeveynleri ile yürütüldü. Veriler Ekim 2016 and Mayıs 2017 tarihleri arasında toplandı. Verilerin toplanmasında“ "Kişisel Özellikler İçin Bilgi Formu” ve "Ebeveyn İzleme Ölçeği” kullanıldı. Verilerin istatistiksel analizi için SPSS 21.0 paket yazılımı kullanıldı. Araştırmanın yürütülmesi için etik kurul ve kurum izni alınmıştır.

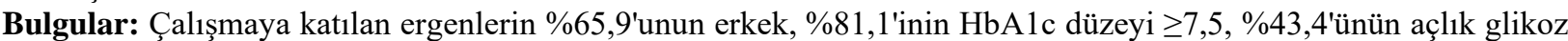

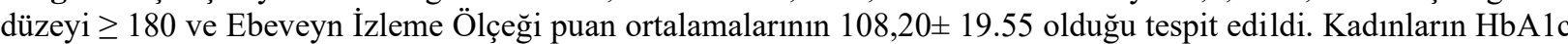
değerlerinin erkeklerin $\mathrm{HbA} 1 \mathrm{c}$ değerlerinden düşük olduğu belirlenmiştir $(\mathrm{p}<0.01)$. Annenin eğitim durumu HbA1c değerleri üzerinde anlamlı bir etkiye sahipti $(\mathrm{p}<0.01)$.

Sonuç: Ebeveyn bakımının adölesanlarda metabolik parametreler üzerinde önemli etkisinin olduğu sonucuna varılmıştır.

Anahtar kelimeler: Ergen, Diyabet bakımı, Ebeveyn kontrolü, Metabolik Parametreler, Tip 1 Diyabet.

\section{Abstract}

Objective: The study was conducted to determine the effect of parental monitoring in diabetes care on compliance to treatment and metabolic parameters in adolescents.

Material and Methods: The study consisted of adolescents with Type 1 diabetes followed up in Endocrinology Outpatient Clinic of Gaziantep Children's Hospital. 132 diabetic adolescents who met the study inclusion criteria were followed up in Endocrinology Outpatient Clinic as well as their parents. Data were collected between October 2016 and May 2017. In order to collect the data, "Information Form for Personal Characteristics" and "Parental Monitoring Scale in Diabetes Care of Adolescents with Type 1 diabetes" surveys have been used. SPSS 21.0 packaged software was used for statistical analysis of the data. Ethics committee approval and institution permission have been obtained for conducting the study.

Results: It was found that $65.9 \%$ of the adolescents participating in the study were male, $81.1 \%$ had poor HbA1c levels of $\geq 7.5,43.4 \%$ had poor fasting glucose levels of $\geq 180$ and above and their mean scores of Parental Monitoring Scale were $108.20 \pm 19.55$. It was determined that HbA1c values of the women were lower than HbA1c values of the men $(\mathrm{p}<0.01)$. Mother's education status had a significant effect on HbA1c values $(\mathrm{p}<0.01)$.

Conclusion: It was concluded that parental care has a significant effect on metabolic parameters in adolescents.

Keywords: Adolescent, Diabetes care, Metabolic parameters, Parental monitoring, Type 1 Diabetes. 


\section{Introduction}

Although the prevalence of Type 1 diabetes is 5-10\% (3$5 \%$ in Turkey) in diabetes patients, it is one of the most common diseases in childhood. It is estimated that approximately 542000 children worldwide have Type 1 diabetes and Type 1 diabetes develops in 86000 children under the age of 15 [1-3].

The presence of the disease in the child causes significant changes in family order. The life of the family before the pediatric child becomes ill will completely transform and the sick child along with the mother, father and siblings and the close circle will be adversely affected by the disease due to the reasons such as increased costs, stress and tension caused by the treatment process [4-6] Adolescent period is the transition period from childhood to adulthood. It is a period where physical, hormonal, sexual, psychosocial, emotional and mental changes and development continue rapidly in the child. The feature of adolescent period is rapid physical growth, sexual maturation, and psychosocial development. Adolescence period forms the developmental roles that must be acquired along with many physiological changes [7-9] In the case of diabetes, which is a chronic disease, it may not only be difficult for the adolescent to perform his/her responsibilities related to the disease along with his/her developmental roles but also the psychological and emotional well-being of both the adolescent and the family undergo a change $[7,10]$. Although adolescence period is a period when the individual has the highest level of knowledge and self-care about Type 1 diabetes, it is a period when the management and metabolic control of the disease is the most difficult and the children and parents have the most problems. The psychosocial problems experienced by the adolescents concerning the management of the disease increase the risk of development of micro vascular complications by preventing the metabolic control to be at the desired level [4,11-13]. In this case, parental monitoring is important for adolescent health. Parental monitoring are the parental attitudes that cover communication between the adolescent and the parent and monitor the location and activities of the adolescent as well as kinds of his/her responsibility in management of the disease [5,14]. In the study conducted with adolescents with Type 1 Diabetes, it was determined that diabetic ketoacidosis picture was more common in patients with negative perceptions towards their parents. In order to manage diabetes well, it has been recommended to increase the practical applications for eliminating the problems between adolescents and parents and strengthening communication between them. If it is well managed, diabetes enhances the quality of life of the adolescent $[11,12]$. It is believed that the self-esteem affected by the internal and external factors in adolescence period can change adaptation to Type 1 diabetes psychologically $[12,15,16]$. Therefore, the study was conducted to determine the effect of parental monitoring in diabetes care on compliance to treatment and metabolic parameters in adolescents in order to determine the problems that may affect negatively the metabolic control in adolescence period and to prevent these problems with appropriate interventions.

Research questions

1- Does parental care have an effect on diabetic parameters?

\section{Materials and Methods}

This study was planned as a correlational, cross-sectional and descriptive study in order to investigate the effect of parental monitoring in diabetes care on the compliance to treatment and metabolic parameters in adolescents. The study was conducted with 132 diabetic adolescents meeting the inclusion criteria of the study and their parents in Endocrinology outpatient clinic in Gaziantep Children's Hospital between October 2016 and May 2017. The inclusion criteria for the individuals participating in the study were determined as follows; being in the age range of 11 and 18 years, being voluntary to participate in the study, being diagnosed with diabetes for at least 1 year, having a family member (mother/father or the person responsible for diabetes monitoring) and being able to speak Turkish.

\subsection{Data Collection Tool}

In order to collect data, "Information Form for Personal Characteristics" and "Parental Monitoring Scale in Diabetes Care of Adolescents with Type 1 Diabetes" were used.

Information Form for Personal Characteristics:

The Information Form for Personal Characteristics prepared by the researcher consists of 2 sections. The first part includes 14 questions about socio-demographic characteristics of the adolescents such as age, gender, number of siblings, birth place, parents' educational level, parents' working status, family type, diabetes related information, and parameters $(\mathrm{HbA} 1 \mathrm{c}$, average glucose (AG) levels, daily dose of insulin) and the second part includes 2 questions questioning the parent's gender and income status. Preliminary application was conducted with 10 adolescents and their families through face-to-face interview method in order to evaluate whether the questionnaire prepared by the researcher was comprehensible or not. There were no problems for the questions such as not understood or misunderstood, having different expressions.

Parental Monitoring Scale in Diabetes Care of Adolescents with Type 1 Diabetes (Type 1 PMDC):

"Parental Monitoring Scale in Diabetes Care of Adolescents with Type 1 Diabetes" whose Turkish validity and reliability study was conducted by Turk, Karatas and Bektas in 2016 has 27 items. The scale was developed by Ellis et al., in 2008 and revised again by Ellis et al., in 2012. The scale is a 5-point Likert-type scale. It is scored as "at least once a week" "1", "more than once in a day" and " 5 " and as the score increases, parental monitoring increases. The highest score of the scale is 135 and its lowest score is 27 points. The Cronbach's alpha coefficient of the scale was determined as 0.91 . In the study conducted by Türk, Karataş and Bektaş, the Cronbach's alpha value of the scale was 
calculated as 0.85 [17]. It was determined as 0.94 in the study.

\subsection{Data Collection}

The data of the study were collected between October 2016 and January 2017. By interviewing with the managers of the related units before the study, the days when the adolescents meeting the inclusion criteria and their families came to the Endocrine Outpatient Clinic for follow-up were determined. The adolescents meeting the inclusion criteria and their parents were informed about the purpose, method, and content of the study and written and verbal consents of those who agreed to participate in the study were obtained.

The data were collected from the parents by using the face-to-face interview method by providing a calm and appropriate environment in the diabetes training room. HbA1c and AG levels were obtained from the file of the day when the interview with the adolescent was conducted. It took about 10 to 15 minutes to conduct interview with the parent.

\subsection{Data Evaluation}

The data of the study were evaluated in the computer environment. For the statistical analysis of the data, SPSS 21.0 (The Statistical Package for the Social Sciences -PC Version 21.0) packaged software was used. Frequency distribution and arithmetic mean for socio-demographic characteristics of the adolescents with Type 1 diabetes and their parents, arithmetic mean for diabetes parameters, parametric data t-test for the comparison of PMDC scores and pair groups, Chi-square test for the comparison of categorical variables, One-Way Variance Analysis (ANOVA) test for evaluating parametric data with more than two groups were used. Post-hoc Tukey test in homogeneous groups as well as Gabriel test and advanced analysis in non-homogeneous groups were conducted in order to determine which group causes the difference in the data evaluated with ANOVA test. The results of the study were interpreted at confidence interval of $95 \%$ by accepting the value of $p \leq 0.05$ as significant.

\subsection{Ethical Aspect}

Permission has been obtained from the noninterventional research ethics committee of Hasan Kalyoncu University dated 03.06.2016 and numbered 2016-08. There was no conflict of interest among the authors.

\section{Results and Discussion \\ 3.1. Results}

Table 1 shows gender, age, number of siblings, family types, birth places of the adolescents with Type 1 diabetes and different characteristics such as the parents' gender, income status, working status and educational status.

When the distribution of the cases $(n=132)$ in terms of their socio-demographic characteristics was examined, it was observed that they were mostly in the age group of $14-16$ years by $48.5 \%$ in terms of their age distributions, $40.9 \%$ had 4 and more siblings, vast majority of them were male $(65.9 \% ; n=87)$ and based on their distribution of birth place, they were mostly born in the city with the rate of $67.4 \%$. It was determined that a great majority of the mothers $(65.9 \% ; n=87)$ were primary school graduates and $43.2 \%$ of the fathers $(n=57)$ were high school graduates. Nearly all of the adolescents (79.5\%; $\mathrm{n}=105$ ) had a nuclear family, it was found that they were diagnosed with diabetes mostly $(50.0 \%, n=66)$ for $1-3$ years [Table 1].

Table 1. Distribution of Adolescents with Type 1 Diabetes According to their Socio-Demographic Characteristics $(\mathrm{n}=132)$

\begin{tabular}{|l|l|l|}
\hline Socio-Demographic & $\mathbf{n}$ & \% \\
Characteristics & & \\
\hline Age Groups & & \\
13 years and younger & 55 & 41.7 \\
Between 14-16 years & 64 & 48.5 \\
17-18 years & 13 & 9.8 \\
\hline Number of Siblings & & \\
3 and less siblings & 78 & 59.1 \\
4 and more siblings & 54 & 40.9 \\
\hline Gender & & \\
Female & 45 & 34.1 \\
Male & 87 & 65.9 \\
\hline Place of birth & & \\
Village & 6 & 4.6 \\
Town & 5 & 3.8 \\
District & 32 & 24.2 \\
City & 89 & 67.4 \\
\hline Mother's Educational Status & & \\
Primary School & 87 & 65.9 \\
High School & 28 & 21.2 \\
University & 17 & 17.9 \\
\hline Father's Educational Status & & \\
Primary School & 50 & 37.9 \\
High School & 57 & 43.2 \\
University & 25 & 18.9 \\
\hline Family Type & & \\
Nuclear Family & 105 & 79.5 \\
Extended Family & 20 & 15.2 \\
Broken Family & 7 & 5.3 \\
\hline Duration of & & \\
Diabetes & & \\
1-3 Years & & \\
4-6 Years & & \\
7 Years and more & & \\
\hline
\end{tabular}

When the distribution of HbA1c levels of adolescents with Type 1 diabetes was examined, it was observed that the highest was 7.5 and higher at the rate of $81.1 \%$, the lowest was 6.4 and lower at the rate of $5.3 \%$. When the distribution of their AG levels was examined, it was observed that the highest was 180 and higher (43.4\%; $\mathrm{n}=56)$ and the lowest was 89 and lower $(4.5 \% ; n=6)$ [Table 2]. 
Table 2. Distribution of Diabetic Parameters of Adolescents with Type 1 Diabetes $(n=132)$

\begin{tabular}{|lll|}
\hline Diabetic Parameters & n & \% \\
\hline HbA1c Level & & \\
6.4 and lower & 7 & 5.3 \\
Between $6.5-7.4$ & 18 & 13.6 \\
7.5 and higher & 107 & 81.1 \\
\hline AG Level & & \\
89 and lower & 6 & 4.6 \\
Between 90 and 134 & 44 & 33.3 \\
Between 135 and 179 & 26 & 19.7 \\
180 and higher & 56 & 42.4 \\
\hline
\end{tabular}

It was determined that the highest mean HbAlc value between the gender distributions of the cases with Type 1 diabetes belonged to the men with the value of $8.72 \pm 1.70$. The HbA1c values of the women were lower than HbA1c values of men and there was a statistically highly significant difference between gender and $\mathrm{HbA} 1 \mathrm{c}$ values. According to advanced analysis result of post-hoc Tukey test, this difference was caused by the fact that mean $\mathrm{HbA} 1 \mathrm{c}$ value of female cases was lower than men $(p=0.003 ; p<0.01)$. It was determined that AG levels of the women were lower than AG levels of men and there was a statistically significant difference between them. According to the advanced analysis result of Post-hoc Tukey test, this difference was due to the fact that mean AG level of female cases was lower than male cases $[p=$ $0.049 ; \mathrm{p}<0.05$, Table 3].

Table 3. Comparison of Adolescents' Gender with Parents' PMDC Mean scores and Diabetic Parameters (n=132)

\begin{tabular}{|c|c|c|c|c|c|c|}
\hline \multirow{3}{*}{$\begin{array}{l}\text { Scale Score and } \\
\text { Diabetic } \\
\text { Parameters }\end{array}$} & \multicolumn{4}{|c|}{ Gender } & \multirow{3}{*}{$\mathbf{t}$} & \multirow{3}{*}{ p } \\
\hline & \multicolumn{2}{|c|}{ Female $(n=45)$} & \multicolumn{2}{|c|}{ Male $(n=87)$} & & \\
\hline & $\overline{\mathrm{x}}$ & $\mathrm{SD}$ & $\overline{\mathbf{x}}$ & SD & & \\
\hline Scale Score & 107.22 & 19.49 & 108.71 & 19.67 & 0.41 & 0.901 \\
\hline HbA1c & 7.97 & 0.83 & 8.72 & 1.70 & 2.76 & 0.003 \\
\hline Insulin Doses & 43.29 & 14.43 & 44.23 & 13.76 & 0.36 & 0.677 \\
\hline AG Level & 170.98 & 65.70 & 175.57 & 46.93 & 0.46 & 0.049 \\
\hline
\end{tabular}

AG: average glucose, HbA1c: Hemoglobin A1c, $\mathrm{X}^{2}$ :Chi-square test, SD: standard deviation, p: p value

When the adolescents' birth places and parents' PMDC mean scores were compared, it was determined that PMDC mean score of the parents of the diabetic adolescents, who were born in the town, was at the lowest

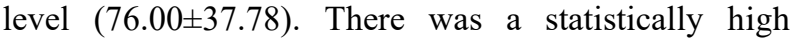
significant difference between the PMDC mean scores of the parents according to the distribution of the adolescents in terms of birth places. According to result of Gabriel test advanced analysis; this difference was due to the fact that the adolescents living in town had lower parental PMDC mean scores compared to other settlement places $(p=0.000 ; p<0.001)$. It was determined according to the birth place of the patients with diabetes that the highest mean $\mathrm{HbAlc}$ value belonged to those who were born in the village with the value of $10.26 \pm 2.44$ $(\mathrm{n}=6)$ and there was a statistically significant difference between the birth places and HbA1c values. This difference was associated with the fact that adolescents living in the city had lower HbA1c values compared to the other settlement places $[\mathrm{p}=0.017 ; \mathrm{p}<0.05$, Table 4].

Table 4. Comparison of Adolescents' Birth Places with Parents' PMDC Mean scores and Diabetic Parameters $(n=132)$

\begin{tabular}{|c|c|c|c|c|c|c|c|c|c|c|}
\hline \multirow{3}{*}{$\begin{array}{l}\text { Scale Score and } \\
\text { Diabetic } \\
\text { Parameters }\end{array}$} & \multicolumn{8}{|c|}{ Birth Places } & \multirow{3}{*}{ f } & \multirow{3}{*}{$\mathbf{p}$} \\
\hline & \multicolumn{2}{|c|}{ Village $(n=6)$} & \multicolumn{2}{|c|}{ Town $(n=5)$} & \multicolumn{2}{|c|}{ District $(n=32)$} & \multicolumn{2}{|c|}{ City $(n=89)$} & & \\
\hline & $\overline{\mathbf{x}}$ & $\mathrm{SD}$ & $\overline{\mathbf{x}}$ & SD & $\overline{\mathbf{X}}$ & SD & $\overline{\mathbf{x}}$ & SD & & \\
\hline Scale Score & 93.33 & 16.82 & 76.00 & 37.78 & 112.28 & 15.25 & 109.55 & 18.00 & 7.17 & 0.000 \\
\hline HbA1c & 10.26 & 2.44 & 8.98 & 1.54 & 8.47 & 1.60 & 8.32 & 1.32 & 3.51 & 0.017 \\
\hline Insulin Doses & 49.33 & 18.01 & 54.20 & 7.82 & 44.91 & 14.76 & 42.61 & 13.47 & 1.54 & 0.207 \\
\hline AG Level & 157.50 & 36.88 & 163.80 & 44.01 & 184.09 & 46.35 & 172.07 & 57.71 & 0.65 & 0.581 \\
\hline
\end{tabular}

AG: average glucose, HbA1c: Hemoglobin A1c, $\mathrm{X}^{2}$ :Chi-square test, SD: standard deviation, p: p value 
When examining the correlation between parental educational statuses of adolescents with Type 1 diabetes and parents' PMDC mean scores, it was seen that PMDC mean score of the primary school graduate parents was lower. A statistically high significant difference was observed between the adolescents' parental educational status and parent's PMDC mean scores. According to the advanced analysis result of post-hoc Tukey test, this difference was due to the fact that the parents having bachelor's degree had higher PMDC mean scores than those with primary school and high school degree $(\mathrm{p}<0.01)$. It was found that the adolescents whose parents were university graduates had the lowest mean HbAlc value. A statistically significant difference was found between the parents' educational status and $\mathrm{HbA} 1 \mathrm{c}$ values. According to the advanced analysis result of posthoc Tukey test, this difference was caused by the fact that the adolescents whose parents were university graduate had lower HbA1c level compared to the others $(\mathrm{p}<0.05)$. A statistically significant difference was determined between the parents' educational status and AG level. According to advanced analysis results of the post-hoc Tukey test, this difference was due to the fact that the mothers with high school degree had lower AG level than those with primary school and bachelor degrees and mean AG levels of the fathers with bachelor degree were lower than mean AG levels of those with high school and primary school degrees $[\mathrm{p}<0.05$, Table 5].

Table 5. Comparison of Adolescents' Parental Educational Status with Parents' PMDC Mean scores and Diabetic Parameters $(\mathrm{n}=132)$

\begin{tabular}{|c|c|c|c|c|c|}
\hline \multirow{2}{*}{$\begin{array}{l}\text { Mother's } \\
\text { Status }\end{array}$} & \multirow{2}{*}{ Educational } & \multicolumn{4}{|c|}{ Scale Score and Diabetic Parameters } \\
\hline & & Scale Scores & HbA1c & Insulin Doses & AG Level \\
\hline \multirow{2}{*}{$\begin{array}{l}\text { Primary } \\
(\mathbf{n}=87)\end{array}$} & $\overline{\mathbf{x}}$ & 104.26 & 8.28 & 43.94 & 183.09 \\
\hline & SD & 20.06 & 1.61 & 13.38 & 55.75 \\
\hline \multirow{2}{*}{ High School $(n=28)$} & $\overline{\mathbf{X}}$ & 113.32 & 8.04 & 43.18 & 152.68 \\
\hline & SD & 7.40 & 0.94 & 14.98 & 51.55 \\
\hline \multirow{2}{*}{ University $(n=17)$} & $\overline{\mathbf{x}}$ & 119.94 & 7.34 & 44.94 & 162.65 \\
\hline & $\mathrm{SD}$ & 13.58 & 0.88 & 14.82 & 34.31 \\
\hline \multicolumn{2}{|l|}{$\mathbf{F}$} & 6.25 & 9.34 & 0.08 & 3.98 \\
\hline \multicolumn{2}{|l|}{$\mathbf{p}$} & 0.003 & 0.000 & 0.919 & 0.021 \\
\hline \multirow{2}{*}{$\begin{array}{l}\text { Father's } \\
\text { Status }\end{array}$} & ional & \multicolumn{4}{|c|}{ Scale Score and Diabetic Parameters } \\
\hline & & Scale Scores & HbA1c & Insulin Doses & AG Level \\
\hline \multirow{2}{*}{$\begin{array}{l}\text { Primary } \\
(n=87)\end{array}$} & $\overline{\mathbf{x}}$ & 100.86 & 8.87 & 44.58 & 169.80 \\
\hline & SD & 21.61 & 1.61 & 13.12 & 60.36 \\
\hline \multirow{2}{*}{ High School $(n=28)$} & $\overline{\mathbf{x}}$ & 108.94 & 8.40 & 43.70 & 185.98 \\
\hline & $\mathrm{SD}$ & 17.86 & 1.52 & 14.35 & 52.00 \\
\hline \multirow{2}{*}{ University (n=17) } & $\overline{\mathbf{x}}$ & 121.20 & 7.83 & 43.04 & 155.12 \\
\hline & $\mathrm{SD}$ & 9.93 & 0.95 & 15.08 & 36.55 \\
\hline \multicolumn{2}{|l|}{$\mathbf{F}$} & 10.39 & 4.26 & 0.11 & 3.203 \\
\hline \multicolumn{2}{|l|}{$\mathbf{p}$} & 0.000 & 0.016 & 0.895 & 0.044 \\
\hline
\end{tabular}

AG: average glucose, HbA1c: Hemoglobin A1c, SD: standard deviation, p: p value

A statistically significant difference was found between the mothers' working status and $\mathrm{HbAlc}$ values. According to the advanced analysis result of the Gabriel test, this difference was caused by the fact that the HbA1c mean values of the working mothers were lower than HbA1c mean values of the non-working mothers $(\mathrm{p}=$ $0.011 ; \mathrm{p}<0.05)$. In terms of the daily insulin doses, a statistically significant difference was observed between 
the adolescents with non-working mothers and the adolescents with working mothers. According to the advanced analysis results of Gabriel test, this difference was associated with the fact that the insulin doses of adolescents with non-working mothers were higher than the insulin doses of the children with working mothers [p=0.031; $<<0.05$, Table 6].

Table 6. Comparison of the Mothers' Working Status with Parents' PMDC Mean scores and Diabetic Parameters $(\mathrm{n}=132)$

\begin{tabular}{|c|c|c|c|c|c|c|}
\hline \multirow{3}{*}{$\begin{array}{l}\text { Scale Score and Diabetic } \\
\text { Parameters }\end{array}$} & \multicolumn{4}{|c|}{ Mother's Working Status } & \multirow{3}{*}{$\mathbf{t}$} & \multirow{3}{*}{$\mathbf{p}$} \\
\hline & \multicolumn{2}{|c|}{ Working $(n=21)$} & \multicolumn{2}{|c|}{ Not working $(n=111)$} & & \\
\hline & $\overline{\mathbf{x}}$ & $\mathrm{SD}$ & $\overline{\mathbf{x}}$ & SD & & \\
\hline Scale Score & 112.47 & 21.41 & 107.39 & 19.17 & 1.09 & 0.277 \\
\hline HbA1c & 7.70 & 0.97 & 8.61 & 1.54 & 2.59 & 0.011 \\
\hline Insulin Doses & 49.90 & 13.74 & 42.77 & 13.75 & 2.17 & 0.031 \\
\hline AG Level & 145.48 & 43.77 & 179.41 & 54.53 & 2.71 & 0.080 \\
\hline
\end{tabular}

AG: average glucose, HbA1c: Hemoglobin A1c, $\mathrm{X}^{2}$ :Chi-square test, SD: standard deviation, p: p value

A statistically high significant difference was determined between the adolescents' family type and their parents' PMDC mean score. According to the advanced analysis result of the Gabriel test; this difference was caused by the fact that adolescents living in a broken family had a lower PMDC mean scores compared to the adolescents living in nuclear and extended families $(p=0.001$; $\mathrm{p}<0.001)$. There was a statistically high significant difference between the family income status and parents' PMDC mean score. According to the advanced analysis results of the Gabriel test, this difference was due to the fact that the adolescents of families who had equal income and expenses had higher parental PMDC mean score compared to the adolescents of families who had incomes higher or lower than their expenses $(p=0.007$; $\mathrm{p}<0.01)$. A statistically high significant difference was determined between the family income status and $\mathrm{HbA1c}$ values. According to the advanced analysis results of the Gabriel test, this difference was caused by the fact that the adolescents living with families having incomes higher than their expenses had lower mean HbA1c value compared to the adolescents living with families having incomes lower than or equal to their expenses $[p=0.005$; $\mathrm{p}<0.01$, Table 7].

Table 7. Comparison of the Adolescents' Family Type and Income Status with Their Parents' PMDC Mean scores and Diabetic Parameters $(\mathrm{n}=132)$

\begin{tabular}{|c|c|c|c|c|c|c|c|c|}
\hline \multirow{3}{*}{$\begin{array}{l}\text { Scale Score and } \\
\text { Diabetic } \\
\text { Parameters }\end{array}$} & \multicolumn{6}{|c|}{ Family Type Status } & \multirow{3}{*}{$\mathbf{f}$} & \multirow{3}{*}{$\mathbf{p}$} \\
\hline & \multicolumn{2}{|l|}{$\begin{array}{l}\text { Nuclear } \\
(n=105)\end{array}$} & \multicolumn{2}{|c|}{$\begin{array}{l}\text { Extended } \\
(n=20)\end{array}$} & \multicolumn{2}{|c|}{$\begin{array}{l}\text { Broken } \\
(\mathrm{n}=70)\end{array}$} & & \\
\hline & $\overline{\mathrm{x}}$ & SD & $\overline{\mathrm{x}}$ & SD & $\overline{\mathrm{x}}$ & SD & & \\
\hline Scale Score & 110.42 & 17.55 & 105.60 & 16.69 & 82.28 & 35.02 & 7.72 & 0.001 \\
\hline HbA1c & 8.42 & 1.54 & 8.32 & 1.43 & 9.55 & 0.70 & 1.99 & 0.141 \\
\hline \multirow{3}{*}{$\begin{array}{l}\text { Scale Score and } \\
\text { Diabetic } \\
\text { Parameters }\end{array}$} & \multicolumn{6}{|c|}{ Family Income Status } & \multirow{3}{*}{$\mathbf{f}$} & \multirow{3}{*}{$\mathbf{p}$} \\
\hline & $\begin{array}{l}\text { Income } \\
\text { than } \\
(n=43)\end{array}$ & $\begin{array}{r}\text { Lower } \\
\text { Expenses }\end{array}$ & $\begin{array}{l}\text { Incom } \\
\text { Expen }\end{array}$ & $\begin{array}{l}\text { Equal to } \\
n=86)\end{array}$ & \multicolumn{2}{|c|}{ Expenses $(\mathbf{n}=3)$} & & \\
\hline & $\overline{\mathbf{X}}$ & SD & $\overline{\mathbf{X}}$ & SD & $\overline{\mathbf{x}}$ & SD & & \\
\hline Scale Score & 101.06 & 23.58 & 112.08 & 15.58 & 99.33 & 30.02 & 5.17 & 0.007 \\
\hline HbA1C & 9.06 & 1.86 & 8.20 & 1.20 & 7.53 & 1.36 & 5.62 & 0.005 \\
\hline
\end{tabular}

HbA1c: Hemoglobin A1c, $\mathrm{X}^{2}$ :Chi-square test, SD: standard deviation, $\mathrm{p}: \mathrm{p}$ value 


\subsection{Discussion}

For adolescents with Type 1 DM and their parents, adolescence period is a period in which the relationship between family and child is reshaped. In this process, adolescents' starting to gain self-care control and taking responsibility for diabetes may trigger conflicts and communication problems between the adolescent and parent.

The most followed parameters in the treatment and care of patients with type $1 \mathrm{DM}$ are AGD and $\mathrm{HbA} 1 \mathrm{c}$ values. According to ADA (2013), HbA1c levels of $\leq 6.4 \%$ refer to good metabolic control, the levels between $6.5-7.4 \%$ refer to moderate metabolic control, and values of $\geq 7.5 \%$ refer to poor metabolic control [18]. When examining HbA1c levels having an important place in metabolic controls of adolescents, it was observed that HbA1c values were higher than the acceptable values. In the similar studies, Frrat [19], Doğan [20], and Yüksel [21] determined that arithmetic mean of $\mathrm{HbA} 1 \mathrm{c}$ values was poor metabolic control with the values of $8.56 \pm 1.6$, $8.3 \pm 1.5$, and $7.9 \pm 1.5$.

Although AG levels varied according to measurement methods, levels of $\leq 89 \mathrm{mg} / \mathrm{dl}$ refer to good metabolic control, levels between $90 \mathrm{mg} / \mathrm{dl}$ and $134 \mathrm{mg} / \mathrm{dl}$ refer to moderate metabolic control, levels between $135 \mathrm{mg} / \mathrm{dl}$ and $179 \mathrm{mg} / \mathrm{dl}$ refer to poor metabolic control and levels of $\geq 180 \mathrm{mg} / \mathrm{dl}$ refer to very poor metabolic control. AG levels of the adolescents included in the study were found to be higher than the acceptable values. Similar to the present study, in the study by Yüksel [21], mean AG levels of the adolescents were found to be poor metabolic control with the value of $172.0 \pm 69.0$.

While the highest score in parental monitoring scale in diabetes care (PMDC) was 135, the lowest score was 27. The higher the scores of the parents, the higher their involvement in the treatment [17]. When the age distribution of the adolescents with Type 1 diabetes included in the study and parental PMDC mean scores were examined, it was observed that PMDC mean scores of the parents of diabetic adolescents in the age group of 17-18 years were lower. Ellis et al., [22] determined in their study that parental care did not have a significant correlation with age but parental care decreased stress and thus increased the adolescent's compliance to treatment. It was thought that increasing age in adolescent caused them to act more independently, they spent time in social environments more and pushed diabetes care into the background; due to such reasons, the communication between parent and adolescent decreased and thus PMDC score of the parents decreased. Similar to the present study, Firat [19], Bozkurt [24], Ellis et al., [22], and Doğan [20] determined in their studies that there was no significant correlation between the adolescent's age and HbA1c values. Karvonen et al., [26], Çıtıl et al., [27], Bayar [28], Çakır et al.,[29] and Frrat [19] determined in their studies that adolescent's age had no significant effect on metabolic parameters. According to these studies, it was observed that the metabolic control of the individuals with good metabolic control decreased significantly as the age of the adolescents with Type 1 diabetes increased. It was thought that this increase was caused not with the increasing age but with the increasing duration of diabetes diagnosis. In parallel with this situation, the metabolic control worsened with increasing age of adolescents and this also caused the daily insulin dosage to increase.

It was seen in the present study that there was a highly significant difference between the gender and HbAlc values of the patients with Type 1 diabetes $(p<0.01)$. In their study, Çitıl et al., [27] found that HbA1c values of men were 1.88 times lower than women. As reported by Bayar [28], it was similarly determined in an international study that glycemic parameters of men were in better level compared to women. In the study conducted by Firat [19] with diabetic children, it was stated that there was no significant difference between HbA1c values and child's gender. In the results of the study conducted by Bayar [28] with patients with Type 1 diabetes, it was determined that women had better HbA1c values than men but no significant difference was found between genders in terms of HbAlc values. The reason for this situation in the present study was believed to be the fact that the male gender can act independently. Mean AG level of female adolescents participating in the present study was seen to be lower than mean AG level of male adolescents. This is believed to be associated with the fact that female patients adopt and comply with the diabetes care better. Similar to the present study, in a study conducted by Demir [30] with adolescents with Type 1 diabetes, metabolic control of men was found to be worse than women. In contrast to the present study, Foulkner and Chang [31] determined in their study that female adolescents had more difficulty in compliance to the diabetes treatment and their compliances were lower. In the study by Aksu [32], it was found that there was no significant difference between metabolic control and gender.

The fact that both parents and other family members (sibling, uncle, aunt) were weak in providing social support to adolescents among adolescents and their parents living in town and parents' attitudes and behaviors and economic status were low was believed to cause adolescents' parental PMDC scores to be low. According to the statement of Bayar [28], as a result of a study conducted to determine the Social Support Levels of Adolescents with Type 1 Diabetes, it was found that adolescents with family support had better glycemic parameters. Main et al.,[33] determined in their study that there was a positive correlation between the socioeconomic level of the family and metabolic controls. In the present study, it was determined that the birth places of the adolescents had a significant effect on HbA1c values $(p<0.05)$. In the study conducted by Bayar [28] with children with Type 1 diabetes, it was determined that $\mathrm{HbA} 1 \mathrm{c}$ values of children living in the village were better than HbA1c values of children living in the town and city center.

It was noticed that parental educational status of the adolescents had a significant effect on parental PMDC 
mean scores, HbAlc values and AG levels ( $\mathrm{p}<0.05)$. In parallel with the present study, in a study conducted by Doğan [20] with 7-12 year-old patients with Type 1 diabetes, children of mothers with high educational level were found to have a better metabolic control. In the study by Melek [34], it was determined that parents' attitudes and behaviors related to diabetes management had a critical place in the glycemic control of children and adolescents with diabetes. It was determined in the study by Ellis et al., [22] that high educational level of parents increased the adolescent's compliance to treatment. It was anticipated that parents with higher educational level might paid more attention to diabetes management education of their children and might get diabetes under control in more accurate way.

In the study conducted by Doğan [20] with adolescents with Type 1 diabetes, it was determined that HbAlc values of children whose mothers were illiterate and primary school graduates were higher with a significant difference from $\mathrm{HbA} 1 \mathrm{c}$ values of children whose mothers had higher education levels. In the study by SerkelSchrama et al., [35], parental educational level was seen to have a significant effect on HbA1c values. In the study by Florian and Elad [36], it was explained that there was a statistically significant difference between the mothers' educational level and adolescents' metabolic control levels. According to the results of the study by Bayar [28], HbA1c values increased to a better level as the parental educational level increased. There are studies expressing opposite opinions of the present study. In the study conducted by Faulkner and Chang [31] on adolescent with Type $1 \mathrm{DM}$, it was determined that the parental educational level had no significant effect on metabolic control. Çakır et al., [29] found in their study that mother's educational level had no significant effect on $\mathrm{HbA1c}$ values.

Parents who do not give enough importance to the diabetes care of adolescent or do not have enough knowledge about this subject may negatively affect the adolescent's compliance to the disease and thus their diabetes management. In the study by Melek [34], it was expressed that metabolic controls of adolescents thinking that their parent had an authoritarian attitude towards them were in poor level; whereas, metabolic controls of adolescents thinking that their parents exhibited democratic attitude towards them were in good level. It is known that the progression of the disease of adolescents with chronic disease varies mostly depending on the parents' attitudes and behaviors and educational levels. These parental attitudes and behaviors are thought to have important effects on adolescent's metabolic parameters and compliance to treatment. It was observed in a study conducted by Faulkner and Chang [31] with adolescents that as their father's educational level increased, adolescents were more successful in controlling blood glucose levels. It was seen in the study by Ellis et al., [16] that adolescents whose mothers had high educational level had better metabolic control. The family of the child with a chronic disease feels serious pressure on themselves. This pressure is mostly taken by mothers. In the study conducted by Doğan [20] with Type 1 diabetic children, it was determined that diabetes responsibility of adolescents was mostly taken by mothers throughout the day. This pressure reflects on adolescents in two ways. Parents show a democratic attitude if they have high educational level and they display an authoritarian attitude if they have low educational level which formed a significant effect on metabolic controls and diabetes management of the adolescent.

It was thought that since working mothers had high educational levels and better financial possibilities compared to non-working mothers, they had a significant effect on diabetes parameters. In the study conducted by Bayar [28] in Mexico, low socio-economic level, lack of social security, and difficulty in meeting treatment costs were determined as a significant risk factor for metabolic control and HbA1c level. In parallel with the present study, it was reported in the study by Doğan [20] that there was a significant correlation between the mother's working status and mean $\mathrm{HbAlc}$ value of the adolescents. In contrast to the present study, it was determined in the study by Güraksin [37] that mother's working status had no significant effect on metabolic parameters.

It was observed that the mean daily insulin dose of diabetic adolescents whose mothers were not working was lower than the mean daily insulin doses used by diabetic adolescents whose mothers were working and there was a positive level difference between them. In the study conducted by Doğan [20] with Type 1 diabetic children, it was determined that mothers took the diabetes care of children with the rate of $90 \%$. It was thought that the insulin doses used daily by the adolescent were controlled more closely by the mothers who were not working.

It was determined that the family type of the adolescents had a significant effect on PMDC mean scores of their parents. It was believed that the PMDC mean scores of the parents were affected by the situations like less social support perceived by adolescents living in extended and broken families, their psycho-physical condition, and the inadequacy of the financial possibilities. In the study by Bayar [28], poor family income status and by divorced parents affected adolescents to come to the outpatient clinics for glycemic control.

As the family income levels of the adolescents participating in the study increased, PMDC mean score of the parents increased but PMDC mean scores of the parents decreased when the family income level increased above a certain level. It was thought that this situation was caused by the problems experienced in reaching to the treatment if the income level is under a certain level; whereas it was caused by parental attitudes and behaviors in adolescents who live with a family having income level higher than a certain level.

In the present study, it was found that the family income status had a high positive correlation on $\mathrm{HbA} 1 \mathrm{c}$ level $(p<0.01)$. Similar to the present study, the results of the studies conducted by Ellis et al. [25], Bayar [28], Öz et 
al., [38] with adolescents having Type 1 diabetes revealed that low family income was effective on metabolic controls. There are also studies that are not in line with the present study. In the study by Bozkurt [24], family income status had no significant correlation on HbA1c level.

\section{Conclusion}

It was concluded in the study that HbAlc values were higher than acceptable values, mean AG levels were higher than the acceptable values, PMDC mean scores of the parents of the adolescents with high age were lower, $\mathrm{HbA1c}$ values of men were lower, mean AG level of female adolescents was lower than mean AG level of male adolescents, birth places of adolescents had a significant effect on PMDC mean scores of the parents and $\mathrm{HbAlc}$ values, parental educational levels had a significant effect on PMDC mean scores of the parents, HbA1c values and AG levels, their mothers' working status had an effect on metabolic parameters and the family type of the adolescent and family income had a significant effect on PMDC mean scores of the parents.

In accordance with these results, it can be recommended to organize comprehensive and continuous training that will give the adolescents and their parents the ability to manage diabetes to provide a good metabolic control, to expand School Health Nursing, for fathers of Type 1 diabetic adolescents to involve in diabetes care and provide them with training that will ensure adolescents to establish a good communication, to evaluate diabetic parameters and plan treatment by considering the individual characteristics of adolescents, ensure and increase access to training, treatment, follow-up and care services for adolescents with type 1 diabetes, provide adolescents with psychosocial support to increase their adherence to diabetes treatment and ensure activation of these mechanisms.

\section{References}

1. Gümüş, E, Çelik, H, Özkan, S, Diabetes Program of Turkey 2015 2020

https://extranet.who.int/ncdccs/Data/TUR_D1_T\%C3\%BCrkiye\%2 0Diyabet\%20Program\%C4\%B1\%202015-2020.pdf, 2014 (accessed 21.02.2017).

2. Johnson, S.B, Baughcum, A.E, Carmıchael, S.K, Shr, J-X, Desmond A, Schatz, Maternal anxiety associated with newborn genetic screening for type 1 diabetes, Diabetes Care, 2004, 27(2).

3. International Diabetes Federation. International Diabetes Atlas. International Diabetes Federation, https://idf.org/e library/epidemiology-research/diabetes-atlas/13-diabetes-atlasseventh-edition.html, 2015 (accessed 21.02.2017)

4. Aschner, P, Horton, E, Leiter, L.A, Munro, N, Skyler, J.S, Practica steps to improving the management of type 1 diabetes: Recommendations from the global partnership for effective diabetes management, International Journal of Clinical Practice, 2010, 64(3), 305-15.

5. Daneman, D, Type 1 diabetes, Lancet, 2006, 367, 847-58.

6. Boztepe, H, A risky period for type 1 diabetes management: adolescence (review), Nursing Journal of Faculty of Health Sciences [Internet]. 2012;82-9. Available from: http://dergipark.gov.tr/download/article-file/88616.

7.Menteş, E, Menteş, B, Obesity and exercise during adolescence period, International journal of Human Sciences, 2011, 8(2), 963-97.

8.Bahíllo, M.P, Hermoso, F, Ochoa, C, García-fernández, J.A, Rodrigo, J, Marugán, J.M, et al. Incidence and prevalence of type 1 diabetes in children aged $<15 \mathrm{yr}$ in Castilla-Leon (Spain), Pediatric Diabetes, 2007, 8(6), 369-73

9. Skyler, J.S, Update on worldwide efforts to prevent type 1 diabetes, Annals of the New York Academy of Sciences, 2008, 1150, 190-6.

10. Buckingham, B, Greenbaum, C.J, Krischer, J, Chase, P, Metabolic tests to determine risk for type 1 diabetes in clinical trials, Diabetes/Metabolism Research and Reviews, 2011, 27(1), 584-9.

11. Streisand, R, Swift, E, Wickmark, T, Chen, R, Holmes, C.S, Pediatric parenting stress among parents of children with type 1 diabetes: the role of self-efficacy, responsibility, and fear, Journal of Pediatric Psychology, 2005, 30(6), 513-21.

12. Laffel, L.M.B, Connell, A, Vangsness, L, Goebel-Fabbri, A, Mansfield, A, Anderson, B.J, General quality of life in youth with type 1 diabetes: relationship to patient management and diabetesspecific family conflict, Diabetes Care, 2003, 26(11), 3067-73.

13. Chien, S.C, Larson, E, Nakamura, N, Lin, S.J, Self-care problems of adolescents with type 1 diabetes in southern taiwan, Journal of Pediatric Nursing, 2007, 22(5), 404-9.

14. Virtanen, S.M, Knip, M, Nutritional risk predictors of $\beta$ cell autoimmunity and type 1 diabetes at a young age, The American Journal of Clinical Nutrition, 2003, 78(6), 1053-67.

15. Anderson, B.J, Vangsness, L, Connell, A, Butler, D, Goebel-Fabbri, A, Laffel, L.M.B, Family conflict, adherence, and glycaemic control in youth with short duration Type 1 diabetes, Diabetic Medicine, 2002, 19(8), 635-42.

16. Ellis, D.A, Podolski, C.L, Frey, M, Naar-King, S, Wang, B, Moltz, K, The role of parental monitoring in adolescent health outcomes: Impact on regimen adherence in youth with type 1 diabetes, Journal of Pediatric Psychology, 2007, 32(8), 907-17.

17. Türk, Ç, Karataş, H, Bektaş, M, Validity and reliability study of parental monitoring scale in diabetes care of adolescents with type 1 diabetes, The Journal Of Pediatric Research, 2016, 3(1), 35-40.

18. Zhang, X, Gregg, E.W, Williamson, D.F, Barker, L.E, Thomas, W, Bullard, K.M.K, et al. A1C level and future risk of diabetes: A systematic review, Diabetes Care, 2010, 33(7), 1665-73.

19. Frrat, E, Investigation of factors affecting quality of life of 13-16 age type 1 diabetic children, social work program master thesis, hacettepe university institute of social sciences, Ankara, 2014

20. Doğan, Z, Diabetes managements of 7-12 year-old children with type 1 diabetes, followed up in the university hospitals, in school environments. Istanbul University, 2009.

21. Yüksel, S, Evaluating sleep quality, anxiety, depression and quality of life in patients with type 1 ve type 2 diabetes, Afyon Kocatepe University, 2007.

22. Ellis, D, Frey, M, Naar-King, S, Templin, T, Cunningham, P, Cakan, $\mathrm{N}$, Use of multisystemic therapy to improve with type 1 diabetes in chronic poor, Diabetes Care, 2005, 28(7), 1064-610.

23. Temel, E, Bahar, A, Çuhadar, D, Determining stress coping styles and depression levels of nursing students, Journal of Firat Health Service, 2007, 2(5), 107-18.

24. Bozkurt, D, Retrospective evaluation of patients applying to pediatric emergency and endocrine outpatient clinic due to diabetic ketoacidosis. Dicle University, 2013.

25. Ellis, D.A, The effects of multisystemic therapy on diabetes stress among adolescents with chronically poorly controlled type 1 diabetes: findings from a randomized, controlled trial, Pediatrics, 2005, 116(6), 826-32

26. Karvonen, M, Viik-Kajander, M, Libman, I, LaPorte, R, Tuomilehto, J, Moltchanova, E, et al. Incidence of childhood type 1 diabetes, Diabetes Care, 2000, 23(10), 1516-26.

27. Citil, R, Günay, O, Elmali, F, Öztürk, Y, The effects of medical and social factors on the quality of life of diabetic patients, Erciyes Medical Journal, 2010, 32(4).

28. Bayar, B, Bio-Psycho-Socio-Cultural and economic factors influencing hba1c value of children with type 1 diabetes mellitus, Düzce University; 2014

29. Çakir, S, Sağlam, H, Özgür, T, Eren, E, Tarim, Ö, Factors affecting glycemic control of children type 1 diabetes, The Journal of Current Pediatrics, 2010, 8(1), 7-19.

30. Demir, E, Examining knowledge, attitude, and behaviors of diabetic patients about diabetes and diabetic foot wound. Istanbul University; 2014

31. Faulkner, M.S, Chang, L.I, Family influence on self-care, quality of life, and metabolic control in school-age children and adolescents with type 1 diabetes, Journal of Pediatric Nursing, 2007, 22(1), 5968 
32. Aksu, M, Consumption of sweeteners and sugared foods in children and adolescents with type 1 diabetes. Haliç University; 2012.

33. Main, A, Wiebe, D.J, Van, B.K, Turner, S.L, Tucker, C, Butner, J.E, et al. Secrecy from parents and type 1 diabetes management in late adolescence, Journal of Pediatric Psychology, 2015, 40(10), 1075 84.

34. Melek, S, The effect of parenteral attitudes on quality of life of adolescents with type 1 diabetes. Erciyes University; 2014.

35. Serkel-Schrama, I.J.P, Vries. J, Nieuwesteeg, A.M, Pouwer, F, Nyklíček, I, Speight, J, et al. The association of mindful parenting with glycemic control and quality of life in adolescents with type 1 diabetes: results from diabetes miles - the netherlands, Mindfulness, 2016, 7(5), 1227-37.

36. Florian, V, Elad, D, The impact of mothers' sense of empowerment on the metabolic control of their children with juvenile diabetes, Journal of Pediatric Psychology, 1998, 23(4), 239-47.

37. Güraksın, Ö, Evaluating adiponectin and leptin levels in 3-18-yearold patients with type 1 diabetes. Afyon Kocatepe University; 2011.

38. Öz, R, Yılmaz, H.B, Akçay, N, Factors affecting self-esteem in children with type 1 diabetes, International Journal of Human Sciences. 2009, 6 (January 2009).

http://edergi.cbu.edu.tr/ojs/index.php/cbusbed isimli yazarın CBU-SBED başlıklı eseri bu Creative Commons Alınt1-Gayriticari4.0 Uluslararası Lisansı ile lisanslanmıştır

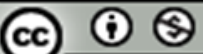

